\title{
Adopting Measures to Increase Alumni Donations at Prestigious Universities
}

\author{
Aftab Dean ${ }^{1} \&$ John Graeme McLean ${ }^{2}$ \\ ${ }^{1}$ Leeds Business School, Leeds, UK \\ ${ }^{2}$ Institute of Continuing Education, University of Cambridge, Cambridge, UK \\ Correspondence: John Graeme McLean, Selwyn College, University of Cambridge, Grange Road, Cambridge, \\ CB3 9DQ, UK. E-mail: jm2270@cam.ac.uk
}

Received: August 4, 2021

doi:10.5539/ijbm.v16n12p27
Accepted: October 12, 2021

Online Published: November 12, 2021

\begin{abstract}
This research uniquely aims to identify the key factors that current students at prestigious universities indicate have influence upon their likelihood of making donations to their alma mater in the future. Using data and examples from both the UK and the USA we show the importance of voluntary donations to prestigious universities and suggest that UK universities have much to learn from their American counterparts. A novel questionnaire was administered to students studying at a number of prestigious UK universities which resulted in a large number of responses being accepted for inferential statistical analysis. The robust results provide new insight into the significance of student centred pedagogy and students' career and financial aspirations as major determinants of intention to donate and also confirm the importance of overall student satisfaction, acquisition of transferable skills and the social experiences of university as additional determining factors. It is intended that this research should have practical implications and so we emphasise elements of the student and pedagogical experience upon which universities and alumni departments should focus their resources in order to increase the likelihood of obtaining future alumni donations from their current students.
\end{abstract}

Keywords: alumni, aspirations, donations, graduate income, prestigious universities, student centred pedagogy, transferable skills

\section{Introduction}

Universities are facing increasing operating costs and have, consequently, become more reliant upon private donations (Weerts \& Ronca, 2009; Tsao \& Coll, 2005; Cunningham \& Cochi-Ficano, 2001). In recent years, universities have had to deal with falling public funding (Stephenson \& Yerger, 2014) as well as the increasing competition for globally mobile students. Moreover, they must now learn how to cope with the impact of the COVID-19 pandemic. Some prestigious UK universities have declared that they expect to lose hundreds of millions of pounds in 2021 due to lost accommodation, catering and conference season income, and the decline in international student numbers and falling research grants (Adams \& Carrell, 2020). This all places even greater importance on attracting private donations (Francioni et al., 2020) to shore up university finances (Iskhakova, Hilbert, \& Joehnk, 2020) and upon establishing what most influences the propensity to donate amongst alumni. Alumni donations are a particularly important source of university revenue, allowing diversification of income (Bastedo, Samuels \& Kleinman, 2014; Dennis, Papagiannidis, Alamanos, \& Bourlakis, 2016). Whilst this area of research has been receiving increasing attention (Baruch \& Sang, 2012; Drezner \& Huehls, 2014), additional and more contemporary work is needed to fully understand the reasons why people make gifts to their Higher Education Institution (HEI).

\section{Alumni Donations}

The widespread introduction of student fees, coupled with a reduction in financial support from public sources, has heightened the urgency for universities to obtain funds from additional sources (Lertputtarak \& Supitchayankool, 2014). Earlier research has determined that a very large proportion of alumni do not make donations to their alma mater (Kaplan, 2017) and that not enough is known about alumni opinions, beliefs and preferences. Indeed, there is a lack of contemporary research in the field of alumni funding, particularly outside of the USA. Private colleges and universities in the USA rely more upon donations from alumni to fund capital 
expenditures, create endowments and help towards general operating costs than do public education institutions (Holmes, 2009). Skari (2014) suggests that alumni represent the greatest unexploited potential source of university donors and Kaplan (2012) notes that, of the private donations received by HEIs in the USA (in 2011), only $27 \%$ of the total came from alumni. In 2019, HEIs in the USA received their highest ever level of support from voluntary givers (alumni, corporations, foundations, non-alumni individuals and other organisations) and the overall value of donations had been increasing for each of the previous ten years (Council for Advancement and Support of Education). Prestigious universities in the UK are falling far short of their U.S. counterparts in attracting alumni donations and, consequently, enjoy far smaller endowments (see Table 1).

Table 1. Endowments of wealthy HEIs in the USA and the UK

\begin{tabular}{lll}
\hline Nation & Higher Education Institute & Endowment \\
\hline USA & Harvard & $\$ 40.8$ billion \\
USA & Yale & $\$ 30.3$ billion \\
USA & Stanford & $\$ 26.5$ billion \\
USA & Princeton & $\$ 26.1$ billion \\
UK & Cambridge & $\$ 4.15$ billion \\
UK & Oxford & $\$ 3.89$ billion \\
UK & Imperial College London & $\$ 580.34$ million \\
\hline
\end{tabular}

Note. Data collected from the website of each HEI, March 2020.

Harvard is the HEI with the largest known endowment (see Table 1), and it is noteworthy that the first alumni giving in America began at Harvard College (established in 1636) with an in-kind donation of land by four of its alumni in 1648 (Markoff, 1978). However, in spite of having received donations early in their history, it took almost two centuries for America's HEIs to develop strategic initiatives to engage with their alumni to gain their support and philanthropy (Curti \& Nash, 1965). In the UK, however, only two universities have come remotely close to emulating the success of their U.S.A. counterparts in this regard. In 2017, Oxford and Cambridge universities combined received $46 \%$ of all new university donations in the UK and attracted $34 \%$ of donors (Weale, 2017). However, the overall size of their endowments, as Table 1 shows, remains significantly below that of the leading U.S. institutions.

The significance of the prestigious universities attracting the greatest magnitude of donations correlates with work by Terry and Macy (2007) that noted that the entry selectivity of an alma mater, as well as its general prestige, impacted upon graduates' propensity to donate and additionally found that graduates were more likely to donate if they believed their alma mater to already be a successful institution. Numerous studies (Holmes, 2009; Sung \& Yang, 2008; Cunningham \& Cochi-Ficano, 2001; Baade \& Sundberg, 1996) concluded that donations and the intention to be supportive of an alma mater were significantly influenced by its perceived prestige. Liu's (2006) predictive model of anticipated donor contributions for public institutions found that being ranked higher in the US News and World Report university league table is positively associated with alumni giving.

At a time when universities are becoming increasingly reliant upon voluntary donations, it is worrying that the scale of alumni donations might continue, or even accelerate in, its recent decline (see Table 2, highlighted row) as the continuing and long-term effects of COVID-19 hit graduate employment and income levels. There is, therefore, heightened urgency for HEIs to understand the key factors that influence students and graduates, now and in the future, to donate to their alma mater. 
Table 2. Estimated Voluntary Support of Higher Education by Source and Purpose, 2018 and 2019, U.S. HEIs.

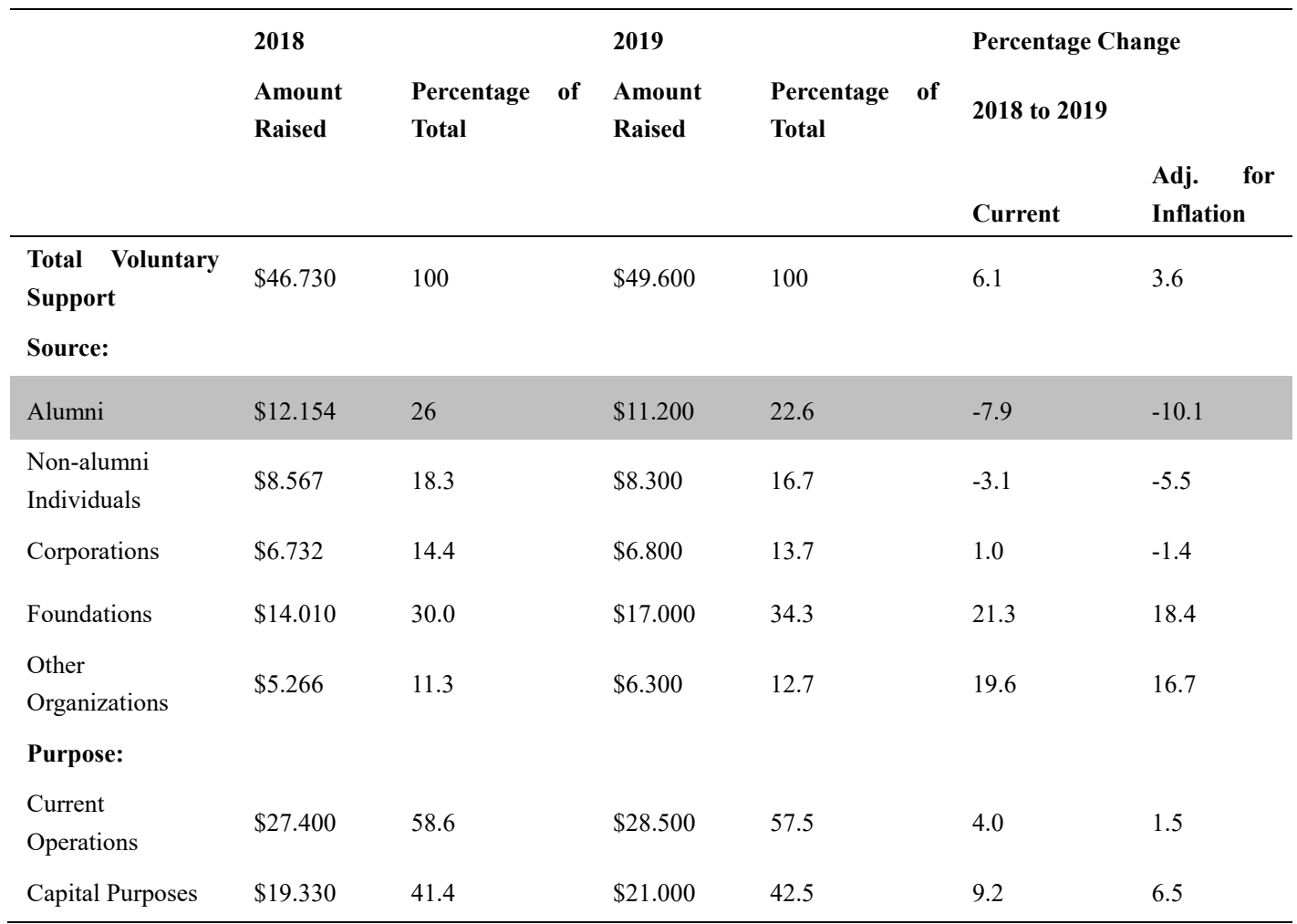

Note. U.S. Dollars in Millions. Adapted from Voluntary Support of Education Key Findings, 2018-19 (Council for Advancement and Support of Education, 2019).

Some colleges and universities in the USA have effectively reduced their tuition fees in order to attract those families who have been priced out of the market for education (Ehrenberg, 2012; Hemelt \& Marcotte, 2011) by providing increasing numbers of scholarships and other gifts whilst turning to donations to provide the necessary funding for these incentives (Ehrenberg, 2012; Hillman, 2012). Such student scholarships are being funded by individual gift-givers at an increasing rate (Kaplan, 2017). HEIs have an incentive to offer these scholarships, with student debt being determined as the most statistically significant (negative) indicator of likelihood of being an alumni donor (Terry \& Macy, 2007). Marr, Mullin, and Siegfried (2005) found that receiving a scholarship increases the likelihood of a student being a future alumni donor. However, later work by Meer and Rosen (2012) suggested that receipt of a scholarship did not affect propensity to be a donor and that, should a scholarship recipient become a future donor, the value of any donation was likely to be comparatively less than from graduates who had not received scholarships.

The propensity to be an alumni donor is mostly a function of income and the personal/family demographics of the donor (Weerts \& Ronca, 2007; Connolly \& Blanchette, 1986). Those alumni most likely to donate are the wealthiest (Baade \& Sundberg, 1996; Clotfelter, 2001; Holmes, 2009). Studies also suggest that such donors are also likely to make charitable donations to a multitude of institutions or organisations (Okunade, 1993; Weerts \& Ronca, 2008; McDearmon \& Shirley, 2009). In addition to income levels, the attributes of gender and age are significant factors in alumni giving, with older alumni most likely to be donors (Weerts \& Ronca, 2009; Dean, 2007; Caboni \& Eiseman, 2003; Bingham, Quigley, \& Murray, 2002; Clotfelter, 2001; Belfield \& Beney, 2000; Okunade, Wunnava, \& Walsh, 1994). This could be attributed to the financial success the alumni have achieved over their career and a desire to contribute back to society (Weerts \& Hudson, 2009). Gunsalus (2004) found a positive correlation between the likelihood of being an alumni donor and the institution's rates of graduation and first year retention as well as the level of tuition fees and the number of students based on campus. However, the most recent graduates were found to be less likely to donate than those who had graduated a greater number of years earlier (Caboni \& Eiseman, 2003; Dean, 2007) and those alumni who live closest to their old university are more likely to make charitable donations to it (Holmes, 2009; McDearmon \& Shirley, 2009). 
Drezner (2013) highlights the importance of any positive form of interaction between alumni and their alma mater. There are numerous, non-monetary means through which alumni may support their alma mater, such as donating their time to promote the university to potential applicants, attending reunions and other alumni functions, volunteering or taking part in research activities or acting as mentors (Sung \& Yang 2009; Gallo 2018; Francioni et al., 2020; Mael \& Ashforth, 1992; McDearmon 2013). Being involved with the alma mater in terms of participation in events and activities is positively correlated with propensity to donate (Dean, 2007; Stephenson \& Yerger, 2014). Alumni donors, with their personal connections to their alma mater, may be more able than other donors to influence external parties due to their strong networking potential and those who volunteer their time to the service of their alma mater are more likely than others to make additional gifts (Weerts \& Ronca, 2007).

Being involved in extracurricular activities, such as special interest groups and clubs, during time at university has been shown to positively impact upon the likelihood of graduates being donors (Tsao \& Coll, 2005; Monks, 2003; Clotfelter, 2001; Okunade et al., 1994). Gaier (2005) found that, if an undergraduate participated in at least one formal extracurricular activity whilst at university, he or she is $87 \%$ more likely to be a graduate donor. Additionally, that same student is $154 \%$ (1.5 times) more likely to participate in the life of their university after graduation. These findings are commensurate with earlier studies that determined the importance of extracurricular activities and the social system within a university to be very important influencers in creating the overall undergraduate experience (Casebeer \& Miller, 1990; Astin, 1984; Astin 1993). Graduates are also more likely to be alumni donors if they engaged with activities in their student residence, such as with governance matters, or were members of religious or performing arts groups (Monks, 2003; Clotfelter, 2003; Gaier, 2005).

Holmes (2009) considered the literature on whether the sporting success of HEIs affected their levels of alumni donations and found the evidence to be inconclusive. However, other studies showed a positive correlation between sports facilities and donations (Marr et al., 2005; Monks, 2003). Skari (2014) argues that extracurricular activities afford opportunities for students to nurture relationships not only with other students but potentially also with staff and faculty, making them more likely to be alumni donors (Clotfelter, 2001; Monks, 2003; Sun, Hoffman, \& Grady, 2007).

Clotfelter's (2002) logistic regression model highlighted two main factors in predicting likelihood to donate and they were levels of income (commensurate with other studies as discussed above) and also satisfaction with the institution. Student satisfaction is a key metric applied in many national surveys such as the National Student Survey (NSS) in the UK and the National Survey of Student Engagement (NSSE) in the USA. Monks (2003) found that the most statistically significant indicator of the likelihood to make donations was the feeling of satisfaction related to undergraduate years. Gaier (2005) found that graduates who were satisfied with the faculty that taught them were more likely to be donors as are those who fondly recollect their time spent at university (Stephenson \& Yerger, 2014).

Sun et al. (2007) proposed an alumni-giving decision model, with the alumni donation being the outcome of the student experience, alumni experience, alumni motivation, and demographic predictor variables. The study suggests that those with greater satisfaction in their student experience were more likely to report that they would donate. The design of Sun et al.'s model is helpful as a foundation for predicting potential alumni donors, but the variables used in this model are too broad to pinpoint what specifically about a satisfying student experience influences an individual to be a donor. Suggesting a similar approach, Weerts and Ronca (2007) recommend that universities focus on the quality of their educational programmes in order to increase student engagement which will ultimately lead to a greater number of graduates becoming alumni volunteers.

\section{Methodology}

Much of the research on predictors of alumni giving has come from USA studies and has involved quantitative methods, mostly employing regression analysis models. These studies have mostly made use of established data sets from a variety of annual student cohorts such as the College and Beyond data set, Alumni Outcomes survey and the US News and World Report rankings (Clotfelter, 2003; Gallo \& Hubschman, 2003; Gunsalus, 2004). Our study gathered its own data set, by deploying a survey instrument to capture responses from a relatively large number of current undergraduate students at a small number of prestigious English universities.

Our student university experience questionnaire was developed based on themes identified in the literature and in both the NSS and the NSSE questionnaires relating to student learning experiences. Additionally, our research instrument included themes related to student career and income aspirations and a broader theme of social experiences. These themes are currently under-researched, and the authors argue that they are critical themes that contribute to the overall student experience. The questionnaire was administered at several Russell Group 
universities across England. The Russell Group is a self-appointed group of universities which claims to represent the UK's leading research universities. (In some respects, the Russell Group may be considered to be analogous to the Ivy League in the USA.)

This research study aims to identify which student experiences have a positive impact on expressed intentions to donate to the alma mater in later life.

The key hypotheses to be tested are:

$\mathrm{H} 1$ - an enriched pedagogical learning experience will influence student intention to donate

$\mathrm{H} 2$ - confidence in achieving career aspirations will influence student intention to donate

$\mathrm{H} 3$ - confidence in achieving future income expectations will influence student intention to donate

$\mathrm{H} 4$ - overall satisfaction with the university experience will influence student intention to donate

\subsection{Student University Experience Survey Questionnaire}

A draft questionnaire of over 60 questions relating to student university experiences, satisfaction and aspirations was derived from the literature. The questionnaire was scrutinised for its relevance by representatives of two students' unions as well as our focus group of current students. This robust approach resulted in the acceptance of 42 questions being adopted in our data model. The questions were divided into seven themes: Teaching and Learning; Assessment; Course Administration; Skills Acquired (transferable skills to help secure employment after graduation) at university; Learning Resources; Social Experiences; Aspirations; Intention to Donate. As a final check on the wording of the questionnaire it was administered to a small pilot sample (30) of students of various backgrounds and ages.

\subsection{General Descriptive Results}

The administration of the survey instrument resulted in 518 reliably completed questionnaires from undergraduate, full-time UK students (at English Russell Group universities). The selection criteria revealed a final sample of 427 students that represented a fairly equal distribution by gender, as can be seen in Table 3 .

Table 3. Sample demographics

\begin{tabular}{lll}
\hline Sample Characteristics & & Percentage \\
\hline \multirow{2}{*}{ Gender } & Male & $47.8 \%$ \\
& Female & $52.2 \%$ \\
\multirow{3}{*}{ Year of Study } & First & $36.8 \%$ \\
& Second & $33.7 \%$ \\
& Final & $29.5 \%$ \\
Age & Under 20 & $36.2 \%$ \\
& 20 & $28.9 \%$ \\
& 21 & $20.9 \%$ \\
\hline
\end{tabular}

\subsection{Statistical Considerations}

Before beginning work on inferential data analysis, statistical tests are run to consider whether the data for the 42 questions relating to student experience in higher education is parametric or non-parametric as this determines which statistical analysis tools will be relevant to the data sets under investigation. The results in Table 4 confirm that our data meets the conditions of parametric acceptance and thus inferential analysis can be applied because both the skewness and kurtosis values are in the range of -2 to +2 , as advocated by George and Mallery (2010). However, a more conservative approach is advocated by Tabachnick and Fidell (2013) who state that an acceptable range for skewness or kurtosis is below +1.5 and above -1.5. Regardless of which measure is adopted, the data meets the criteria for normality. 
Table 4. Means and Skewness and Kurtosis variables identified as contributing to an enhanced student experience in $\mathrm{HE}$

\begin{tabular}{|c|c|c|c|c|c|c|}
\hline & $\mathrm{N}$ & Mean & Median & $\begin{array}{l}\text { Std. } \\
\text { Deviation }\end{array}$ & Skewness & Kurtosis \\
\hline Tutors are friendly and approachable & 427 & 5.36 & 6.00 & 1.069 & -0.706 & 0.388 \\
\hline Tutors concerned for student wellbeing & 427 & 4.91 & 5.00 & 1.332 & -0.456 & -0.204 \\
\hline Tutors inspire me to achieve my potential & 427 & 4.76 & 5.00 & 1.337 & -0.344 & -0.296 \\
\hline Lectures and seminars are interesting & 427 & 4.01 & 4.00 & 1.375 & -0.028 & -0.601 \\
\hline Tutors amenable to contact & 427 & 5.47 & 6.00 & 1.224 & -0.963 & 0.796 \\
\hline Tutors use real world examples & 427 & 5.06 & 5.00 & 1.420 & -0.617 & -0.180 \\
\hline Sufficient online learning materials & 427 & 5.43 & 6.00 & 1.275 & -0.777 & 0.461 \\
\hline Tutors committed to teaching & 427 & 4.60 & 5.00 & 1.640 & -0.157 & -0.836 \\
\hline Variety of assessment methods used & 427 & 4.35 & 5.00 & 1.575 & -0.169 & -0.840 \\
\hline Opportunities to discuss assessment & 427 & 4.80 & 5.00 & 1.451 & -0.521 & -0.367 \\
\hline Assessments are relevant to course & 427 & 5.67 & 6.00 & 1.276 & -0.996 & 0.665 \\
\hline Assessment guidance given & 427 & 5.23 & 5.00 & 1.262 & -0.702 & 0.722 \\
\hline Assessments disseminated early in the semester & 427 & 5.27 & 5.00 & 1.365 & -0.618 & -0.146 \\
\hline Feedback identifies areas that need improvement & 427 & 4.52 & 5.00 & 1.421 & -0.285 & -0.439 \\
\hline Considerate timetabling & 427 & 4.75 & 5.00 & 1.493 & -0.428 & -0.354 \\
\hline I Know who to approach if there is an admin issue & 427 & 4.95 & 5.00 & 1.565 & -0.531 & -0.410 \\
\hline I am kept informed of course updates & 427 & 4.88 & 5.00 & 1.416 & -0.532 & -0.152 \\
\hline Admin staff are friendly & 427 & 5.30 & 6.00 & 1.353 & -0.831 & 0.647 \\
\hline Confident in working with Quantitative data & 427 & 4.59 & 5.00 & 1.896 & -0.405 & -0.907 \\
\hline Confident in applying theory & 427 & 5.11 & 5.00 & 1.350 & -0.817 & 0.636 \\
\hline Confident in writing essays / reports & 427 & 5.26 & 6.00 & 1.530 & -0.843 & 0.126 \\
\hline Confident in generating creative solutions & 426 & 5.07 & 5.00 & 1.327 & -0.577 & 0.087 \\
\hline Confident in delivering presentations & 427 & 4.99 & 5.00 & 1.593 & -0.636 & -0.224 \\
\hline Improved Team working skills & 427 & 5.06 & 5.00 & 1.502 & -0.764 & 0.157 \\
\hline Confident in reviewing and critiquing my work & 427 & 5.16 & 5.00 & 1.289 & -0.707 & 0.313 \\
\hline Improved leadership skills & 427 & 4.98 & 5.00 & 1.462 & -0.602 & -0.064 \\
\hline Global issues awareness & 427 & 5.03 & 5.00 & 1.717 & -0.701 & -0.318 \\
\hline Ethical issues awareness & 427 & 5.22 & 5.00 & 1.569 & -0.775 & 0.040 \\
\hline Sufficient library resources & 427 & 5.32 & 6.00 & 1.464 & -0.636 & -0.464 \\
\hline Sufficient library spaces & 427 & 4.85 & 5.00 & 1.621 & -0.401 & -0.766 \\
\hline $\begin{array}{l}\text { SU has sufficient facilities } \\
\text { (bars, cafes, entertainment) }\end{array}$ & 427 & 5.04 & 5.00 & 1.596 & -0.727 & -0.207 \\
\hline Confident to try SU clubs / societies & 427 & 4.93 & 5.00 & 1.444 & -0.507 & -0.109 \\
\hline Prices to join clubs are reasonable & 427 & 4.63 & 5.00 & 1.417 & -0.241 & -0.491 \\
\hline Made friends from many backgrounds & 427 & 5.34 & 6.00 & 1.565 & -0.948 & 0.271 \\
\hline Forged lifelong friendships & 427 & 6.13 & 7.00 & 1.227 & -1.722 & 3.091 \\
\hline Engage in academic discussion with students & 427 & 5.04 & 5.00 & 1.636 & -0.731 & -0.245 \\
\hline Expect career success upon graduating & 426 & 4.69 & 5.00 & 1.360 & -0.308 & -0.178 \\
\hline Expect international career & 427 & 4.49 & 5.00 & 1.663 & -0.293 & -0.693 \\
\hline Intend to pursue career in subject studied & 427 & 5.10 & 5.00 & 1.791 & -0.748 & -0.377 \\
\hline Intend to pursue further HE study & 427 & 4.67 & 5.00 & 1.876 & -0.382 & -0.970 \\
\hline Future income influenced course choice & 427 & 4.05 & 4.00 & 1.936 & -0.076 & -1.119 \\
\hline Future income influenced uni choice & 427 & 4.21 & 4.00 & 2.013 & -0.193 & -1.180 \\
\hline
\end{tabular}

\subsection{Statistical Analysis}

\subsubsection{Factor Analysis}

Orthogonal Varimax rotation was applied to the 42 questions in our survey instrument. The factor results revealed a high KMO (Kaiser-Meyer-Olkin) factor of .847 and a Bartlett's test for Sphericity with a significant chi square value of 5151.05, thus confirming the suitability of the data for factor grouping. The factor analysis test was calibrated to reveal only factor loading greater than .49. This yielded 26 questions that met the criteria, segmented into eight factor groups. We labelled these as: 
1. Student Centred Pedagogy; 2. Relevant Assessment; 3. Acquiring Transferable Skills; 4. Achieving Career Aspirations; 5. Effective Course Admin; 6. Social Engagement; 7. Ethical Awareness and 8. Future Income Expectations. The overall percentage of variance determined by undertaking factor analysis was $48.55 \%$ and this is an acceptable level to permit further statistical analysis on the factor groups.

\subsubsection{Testing for Multicollinearity}

To ensure that the data analysis does not result in any biased findings, especially under regression analysis, it is prudent to test for multicollinearity between the dependent and among the independent variables. Our dependent variable is the student intention to donate to their alma mater and the independent variables are the eight factor groups, as identified, plus the additional independent variable of student satisfaction. Student satisfaction has long been identified as an indicator of intention to donate (see e.g., Clotfelter, 2002 and Mosser, 1993). Multicollinearity can become a problem in the estimation of linear (or generalised linear) data models (including Cox regression and logistic regression). It can occur for numerous reasons, such as inaccurate dummy variable usage, repetition of similar variable types and the inclusion of one or more variables computed from other variables included in the same data set.

When testing for multicollinearity, it is generally held to be true that the correlation coefficient results should be no greater than 0.9 . The results in Table 5 provide evidence that there is no issue of multicollinearity in our data set as all but one of the correlation coefficients between any two variables are less than .5, which Evans (1996) defines as a modest correlation. Thus, regression analysis can confidently be undertaken to identify the key themes that significantly influence student intention to donate to their alma mater in later life.

Table 5: Correlation between Factor Groups and Intention to Donate

\begin{tabular}{|c|c|c|c|c|c|c|c|c|c|c|c|}
\hline & $\begin{array}{l}\text { Student } \\
\text { Centred } \\
\text { Pedagogy }\end{array}$ & $\begin{array}{l}\text { Relevant } \\
\text { Assessment }\end{array}$ & $\begin{array}{l}\text { Acquiring } \\
\text { Transferable } \\
\text { Skills }\end{array}$ & $\begin{array}{l}\text { Achieving } \\
\text { Career } \\
\text { Aspirations }\end{array}$ & $\begin{array}{l}\text { Effective } \\
\text { Course } \\
\text { Admin }\end{array}$ & $\begin{array}{l}\text { Social } \\
\text { Engagement }\end{array}$ & $\begin{array}{l}\text { Ethical } \\
\text { Awareness }\end{array}$ & $\begin{array}{l}\text { Future } \\
\text { Income } \\
\text { Expectations }\end{array}$ & $\begin{array}{l}\text { Satisfied } \\
\text { with } \\
\text { University } \\
\text { Experience }\end{array}$ & $\begin{array}{l}\text { Intend } \\
\text { Donate } \\
\text { University }\end{array}$ & $\begin{array}{l}\text { to } \\
\text { to }\end{array}$ \\
\hline Student & & & & & & & & & & & \\
\hline $\begin{array}{l}\text { Centred } \\
\text { Pedagogy }\end{array}$ & 1 & & & & & & & & & & \\
\hline $\begin{array}{l}\text { Relevant } \\
\text { Assessment } \\
\text { Acquiring }\end{array}$ & $.428 * *$ & 1 & & & & & & & & & \\
\hline $\begin{array}{l}\text { Transferable } \\
\text { Skills }\end{array}$ & $.372 * *$ & $.227 * *$ & 1 & & & & & & & & \\
\hline Achieving & & & & & & & & & & & \\
\hline $\begin{array}{l}\text { Career } \\
\text { Aspirations }\end{array}$ & $.271 * *$ & $.144 * *$ & $.255^{* *}$ & 1 & & & & & & & \\
\hline $\begin{array}{l}\text { Effective } \\
\text { Course Admin }\end{array}$ & $.471 * *$ & $.400 * *$ & $.242 * *$ & 0.077 & 1 & & & & & & \\
\hline $\begin{array}{l}\text { Social } \\
\text { Engagement }\end{array}$ & $.238 * *$ & $.227 * *$ & $.314 * *$ & $.159 * *$ & $.286^{* *}$ & 1 & & & & & \\
\hline $\begin{array}{l}\text { Ethical } \\
\text { Awareness }\end{array}$ & $.158 * *$ & $.206 * *$ & $.314^{* *}$ & $.147 * *$ & $.169 * *$ & 0.075 & 1 & & & & \\
\hline $\begin{array}{l}\text { Future Income } \\
\text { Expectations }\end{array}$ & 0.037 & -0.042 & 0.037 & $.264 * *$ & 0.001 & 0.031 & 0.010 & 1 & & & \\
\hline Satisfied with & & & & & & & & & & & \\
\hline University & $.539 * *$ & $.413 * *$ & $.284 * *$ & $.212^{* *}$ & $.406 * *$ & $.209 * *$ & $.176^{* *}$ & -0.028 & 1 & & \\
\hline Experience & & & & & & & & & & & \\
\hline Intend & & & & & & & & & & & \\
\hline $\begin{array}{ll}\text { Donate } & \text { to } \\
\text { University }\end{array}$ & $.363 * *$ & $.115^{*}$ & $.225^{* *}$ & $.271 * *$ & $.319 * *$ & $.207 * *$ & 0.067 & $.228 * *$ & $.277 * *$ & 1 & \\
\hline
\end{tabular}

Note. *significant at the $95 \%$ level** significant at the $99 \%$ level. 


\subsubsection{Linear Regression of Identified Factor Groups with Intention to Donate}

As noted above, we added to the regression model an additional independent variable, Student Satisfaction with their University Experience. The Regression analysis of the factor groups and this additional independent variable revealed a significant model $(\mathrm{F}=14.37 / 0.000)$ and an $\mathrm{R}$ square of .238 , supporting the predicted model. The regression estimates for each factor group are highlighted in Table 6.

Table 6. Future alumni donation intention regression model

\begin{tabular}{|c|c|c|c|c|c|}
\hline & Unstandardized Coefficients & & Standardized Coefficients & $\mathrm{t}$ & Sig. \\
\hline & $\mathrm{B}$ & Std. Error & Beta & & \\
\hline (Constant) & 3.113 & 0.402 & & 7.746 & 0.000 \\
\hline Student Centred Pedagogy & 0.381 & 0.076 & 0.239 & 4.994 & 0.000 \\
\hline Relevant Assessment & -0.034 & 0.073 & -0.021 & -0.468 & 0.640 \\
\hline Acquiring Transferable Skills & 0.178 & 0.069 & 0.112 & 2.591 & 0.010 \\
\hline Achieving Career Aspirations & 0.308 & 0.070 & 0.193 & 4.401 & 0.000 \\
\hline Effective Course Admin & 0.335 & 0.070 & 0.210 & 4.759 & 0.000 \\
\hline Social Engagement & 0.125 & 0.070 & 0.078 & 1.783 & 0.075 \\
\hline Ethical Awareness & -0.032 & 0.069 & -0.020 & -0.460 & 0.646 \\
\hline Future Income Expectations & 0.285 & 0.069 & 0.179 & 4.138 & 0.000 \\
\hline Satisfied with University Experience & 0.146 & 0.073 & 0.107 & 1.983 & 0.048 \\
\hline
\end{tabular}

The regression analysis of the factor groups revealed two factors with high beta and $t$ values that significantly influenced student intention to donate to their alma mater, namely: Student Centred Pedagogy (in which students perceive the whole learning experience as being centred on activities that engage them), and Effective Course Administration (tuition-paying students have expectations as customers of their HEI). Additionally, there were several other significant factors that influence student intention to donate. These include confidence in Achieving Career Aspirations, achieving Future Income Expectations, Acquiring Transferable Skills and being Satisfied with the University Experience.

Engagement in social activities, such as sports and university clubs, is below the cut-off for significance. However, the mean rating for this theme was high. Thus, while it may not be a critical factor in influencing donations specifically, it is nevertheless an important influence on the overall student higher education experience.

\section{Discussion}

The first hypothesis was proven and demonstrated that a student centred pedagogy significantly influences intention to donate to the alma mater in the future. This view is echoed in the research by Weerts and Ronca (2007) who recommend that universities focus on the quality of their educational programmes in order to increase student engagement which will ultimately lead to a greater number of graduates becoming alumni volunteers.

The second hypothesis proposed that students who were confident in achieving their career aspirations were significantly likely to donate to their alma mater. This hypothesis was also proven, and the findings have resonance in the literature which shows that both age and income are significantly related to alumni intention and likelihood to donate (Tsao \& Coll, 2005; Weerts \& Ronca, 2009).

Hypothesis 3, that confidence in achieving future income expectations will influence student intention to donate, was also proven. It is pertinent to note that prestigious universities tend to attract and recruit students from a 
higher socioeconomic background (Cho, Hudley, Lee, Barry, \& Kelly, 2008; Macdonald \& Stratta, 2001; Reay, Ball \& David, 2002). It has been proven that students from higher socioeconomic backgrounds tend to be more successful in achieving their career aspirations and are generally better prepared for the world of work due to better access to resources and career guidance as well as familial experience regarding their higher education choices (Diemer \& Ali, 2009).

The UK's Institute of Fiscal Studies has determined that graduates tend to earn more than $£ 100,000$ over their working lifetime than non-graduates (see Britton, Deardon, van der Erve, \& Waltmann, 2020). However, the increase is not equal among students from the differing socioeconomic backgrounds. Belfield et al. (2018) reveal the significance of a student's socioeconomic background and school leaving grades upon their salary post-graduation. Students from relatively lower socioeconomic backgrounds enjoy a post-graduation salary increase of 3\% for every top grade in their high school leaving exams ('A-Levels' in England). For those from the highest socioeconomic backgrounds, the relative increase is $10 \%$. In this study, Russell Group students significantly indicated that they expected to achieve a high income in the future. This expectation is quantified by commercial job search engine Adzune which determined that Russell Group students can expect to earn significantly more per year than graduates from non-Russell Group universities (Turton, 2017).

The fourth and final hypothesis attempted to determine whether satisfaction with the overall student experience would significantly influence student intention to donate to their alma mater in the future; and was proven (though is less impactful than the variables in the first three hypotheses). These findings resonate with earlier research (Monks, 2003; Dean, 2007; Sun et al., 2007) which found overall satisfaction with time spent at university to be a positive influence on likelihood of being an alumni donor.

\section{Conclusion}

Previous studies have focused upon profiling and targeting alumni to identify their likely intention to donate. This research is the first to consider a range of experiences and aspects of student life, specifically including in-depth analysis of the learning and social experiences as well as career aspirations, to determine their impact on the intentions of current students to donate to their alma mater in the future. We recommend that universities develop a new focus based upon ensuring that their current students will become donors in the future, rather than simply focussing upon existing alumni and hoping that they can successfully profile and target them.

Our results suggest that it is vital that universities invest in a student centred learning experience and that their students acquire the transferable skills required by industry and commerce. At a time when there is a shift towards online learning, universities should be acutely aware of the need to develop an active learning experience which their students feel is centred around them and in which they feel engaged, inspired and empowered.

A particularly unique result of our study is that it demonstrates that current undergraduate students are aware of the need to develop transferable learning skills whilst at university and, moreover, feel able to judge how well their university is equipping them with these skills. Universities should therefore take steps to ensure that their students are fully equipped with the requisite skills to successfully enter the world of work. Additionally, universities should create actionable and inspirational schemes to give their students confidence that they are being guided on the path to achieving their career and future income aspirations and expectations.

Data collected and shown in Table 1 indicate that prestigious universities in the UK are significantly lagging behind their counterparts in the USA in terms of donations received. At a time of increasing pressure on higher education funding, all universities should take note that some of the factors we have identified as being indicators of intention to make future alumni donations also feed into overall satisfaction indicators in the NSSE and the NSS. Universities should therefore elevate the status of their alumni and development offices and ensure that a coordinated approach is taken across all strategic departments such that student centred pedagogy, extra-curricular activities, transferable skills, aspirations and career advancement are at the very heart of each university's mission statement and daily activities.

\subsection{Limitations of Research}

It is recognised that all research projects have limitations to some extent and this research project was undertaken with every precaution to limit any undue factors that could impinge upon the integrity of its findings. One limitation of this research project is that the data gathered by the questionnaire came from students at only a relatively small number of universities. Thus, it is recommended that this study be replicated among a wider sample base, and internationally, to confirm and enrich the findings. 


\section{References}

Adams, R., \& Carrell, S. (2020). UK universities plead for billions of pounds in support. Retrieved August 8th, 2021, from https://www.theguardian.com/education/2020/apr/10/uk-universities-plead-billions-pounds-support

Astin, A. W. (1984). Student involvement: A developmental theory for higher education. Journal of College Student Personnel, 25, 297-308.

Astin, A. W. (1993). What matters in college? Four critical years revisited. Jossey-Bass, San Francisco.

Baade, R. A., \& Sundberg, J. O. (1996). What determines alumni generosity? Economics of Education Review, 15(1), 75-81. https://doi.org/10.1016/0272-7757(95)00026-7

Baruch, Y., \& Sang, K. J. (2012). Predicting MBA graduates' donation behaviour to their alma mater. Journal of Management Development, 31(8), 808-825. https://doi.org/10.1108/02621711211253268

Bastedo, M. N., Samuels, E., \& Kleinman, M. (2014). Do charismatic presidents influence college applications and alumni donations? Organizational identity and performance in US higher education. Higher Education, 68(3), 397-415. https://doi.org/10.1007/s10734-014-9719-z

Belfield, C. R., \& Beney, A. P. (2000). What determines alumni generosity? Evidence for the UK. Education Economics, 8(1), 65-80. https://doi.org/10.1080/096452900110300

Belfield, C., Britton, J., Buscha, F., Dearden, L., Dickson, M., Van der Erve, L., \& Zhu, Y. (2018). The relative Labour market returns to different degrees. Institute of Fiscal Studies, Department for Education. Retrieved from

https://assets.publishing.service.gov.uk/government/uploads/system/uploads/attachment_data/file/714517/T he_relative_labour_market-returns_to_different_degrees.pdf

Bell, A., \& Brooks, C. (2016). What makes students satisfied? A discussion and analysis of the UK's National Student Survey. Journal of Further and Higher Education, 42(8), 1118-1142. https://doi.org/10.1080/0309877X.2017.1349886

Bingham, F. G., Quigley, C. J., \& Murray, K. B. (2002), An investigation of the influence acknowledgement programs have on alumni giving behavior: Implications for marketing strategy. Journal of Marketing for Higher Education, 12(2), 1-14. https://doi.org/10.1300/J050v12n02 01

Blackbaud. (2014). 2013 donor centricsTM annual report on higher education alumni giving summary of annual fund key performance indicators July 2012-June 2013. Retrieved from https://www.blackbaud.com/files/resources/downloads/2014/04-14_TA_donorCentrics_HEAnnualReport UPDATED.pdf

Bolton, P. (2020). Student loan statistics. House of Commons Briefing Paper: No. 1079. Retrieved from https:/commonslibrary.parliament.uk/research-briefings/sn01079/\#: :text=Currently\%20more\%20than\%20 $\% \mathrm{C} 2 \% \mathrm{~A} 317$,the $\% 20$ middle $\% 20$ of $\% 20$ this $\% 20$ century

Bombardieri, Marcella. (2007). Colleges fear debt puts damper on donations. The Boston Globe.

Brittingham, B. \& Pezzullo, T. (1989). Fundraising in higher education: What we know, what we need to know. ERIC Document ED 313988.

Brittingham, B. E., \& Pezzullo, T. R. (1990). The campus green: Fundraising in higher education. ASHE-ERIC Higher Education Reports: Washington, D. C.

Britton, J., Dearden, L., Van der Erve, L., \& Waltmann, B. (2020). The impact of undergraduate degrees on lifetime earnings. Retrieved April 6th, 2021, from https://www.ifs.org.uk/publications/14729

Brodigan, D. L., \& Dehne, G. C. (1997). Data for effective marketing in an uncertain future. Journal of College Admission, 155, 16-21.

Cabrera, A., Weerts, D., \& Zulick, B. (2003). Alumni survey: Three conceptualizations to alumni research. Presented to: Métodos de Análisis de la Inserción laboral de los Universitarios. Universidad de León, Spain. 9th to 11th June, 2003.

Casebeer, A. L., \& Miller, M. T. (1990). Donor characteristics of college of education alumni: Examining undergraduate involvement. ERIC Document Reproduction Service No. ED 323836.

Cho, S., Hudley, C., Lee, S., Barry, L., \& Kelly, M. (2008). Roles of gender, race, and SES in the college choice process among first-generation and non-first-generation students. Journal of Diversity in Higher Education, 
1(2), 95-107. https://doi.org/10.1037/1938-8926.1.2.95

Clotfelter, C. T. (2001). Who are the alumni donors? Giving by two generations of alumni from selective colleges. Nonprofit Management and Leadership, 12(2), 119-138. https://doi.org/10.1002/nml.12201

Clotfelter, C. T. (2002). Alumni giving to elite private colleges and universities. Economics of Education Review, 22, 109-120. https://doi.org/10.1016/S0272-7757(02)00028-6

Clotfelter, C. T. (2003). Alumni giving to elite private colleges and universities. Economics of Education Review, 22(1), 109-120. https://doi.org/10.1016/S0272-7757(02)00028-6

Connolly \& Blanchette. (1986). Understanding and Predicting Alumni Giving Behavior. In J. A. Dunn (ed.). Enhancing the Management of Fundraising. New Directions for Institutional Research, 68-89. https://doi.org/10.1002/ir.37019865107

Connor, H., Dewson, S., Tyers, C., Eccles, J., Regan, J., \& Aston, J. (2001). Social class and higher education: Issues affecting decision on participation by lower social class groups. Institute of Employment Studies. Research Report No. 267. Department of Education and Employment.

Council for Advancement and Support of Education. (2019). Voluntary support of education key findings, 2018-19. Retrieved September 26th, 2020, from https://www.case.org/resources/voluntary-support-education-key-findings-2018-19

Cunningham, B. M. \& Cochi-Ficano, C. K. (2001), The determinants of donative revenue flows from alumni of higher education. The Journal of Human Resources, 37(3), 540-69. https://doi.org/10.2307/3069681

Curti, M. E., \& Nash, R. (1965). Philanthropy in the shaping of American higher education. New Brunswick, NJ: Rutgers University Press.

Dean, M. S. (2007). Perceptions of chief development officers about factors that influence alumni major giving. (Unpublished doctoral dissertation). Southern Illinois University, Carbondale.

Dellow, A. D., \& Romano, R. M. (2002). Editor's choice: Measuring outcomes: Is the first-time cohort appropriate for community college? Community College Review, 30(2), 42-54. https://doi.org/10.1177/009155210203000203

Dennis, C., Papagiannidis, S., Alamanos, E., \& Bourlakis, M. (2016). The role of brand attachment strength in higher education. Journal of Business Research, 69(8), 3049-3057. https://doi.org/10.1016/j.jbusres.2016.01.020

Diemer, M. A., \& Ali, S. R. (2009). Integrating social class into vocational psychology: Theory and practice implications. Journal of Career Assessment, 17, 247-265. https://doi.org/10.1177/1069072708330462

Drezner, N. D. (2013). Expanding the donor base in higher education: Engaging non-traditional donors. Routledge. https://doi.org/10.4324/9780203113714

Drezner, N. D., \& Huehls, F. (2014). Fundraising and institutional advancement: Theory, practice, and new paradigms. Routledge. https://doi.org/10.4324/9780203123850

Ehrenberg, R. G. (2012). American higher education in transition. The Journal of Economic Perspectives, 26(1), 193-216. https://doi.org/10.1257/jep.26.1.193

Evans, J. D. (1996). Straightforward statistics for the behavioral sciences. Pacific Grove, CA: Brooks/Cole Publishing.

Fielding, A., Dunleavy, P. J., \& Langan, A. M. (2010). Interpreting context to the UK's national student (satisfaction) survey data for science subjects. Journal of Further and Higher Education, 34(3), 347-368. https://doi.org/10.1080/0309877X.2010.484054

Francioni, B., Curina, I., Dennis, C., Papagiannidis, S, Alamonos, E., Bourlakis, M. \& Hegner, S. M. (2020). Does trust play a role when it comes to donations? A comparison of Italian and US higher education institutions. Higher Education, 1-21. https://doi.org/10.1007/s10734-020-00623-1

Gaier, S. (2005). Alumni satisfaction with their undergraduate academic experience and the impact on alumni giving and participation. International Journal of Educational Advancement, 5(4), 279-288. https://doi.org/10.1057/palgrave.ijea.2140220

Gallo, M. L. (2018). How are graduates and alumni featured in university strategic plans? Lessons from Ireland. Perspectives: Policy and Practice in Higher Education, 22(3), 92-97. https://doi.org/10.1080/13603108.2017.1397065 
Gallo, P. J., \& Hubschman, B. (2003). The relationships between alumni participation and motivation on financial giving. Paper presented at the Annual Meeting of the American Educational Research Association, Chicago, IL. Retrieved from http://eric.ed.gov/?id=ED477447

George, D., \& Mallery, M. (2010). SPSS for Windows step by step: A simple guide and reference (10th ed.). Boston: Pearson.

Giving USA. (2019). Giving USA 2019: The annual report on philanthropy for the year 2018. Retrieved January 19th, 2021,

from https:/givingusa.org/giving-usa-2019-americans-gave-427-71-billion-to-charity-in-2018-amid-complex-yea r-for-charitable-giving/

Gunsalus, R. (2004). The relationship of institutional characteristics and giving participation rates of alumni. International Journal of Educational Advancement, 5(2), $162-170$. https://doi.org/10.1057/palgrave.ijea.2140214

Harrison, W. B., Mitchell, S. K., \& Peterson, S. P. (1995). Alumni donations and colleges' development expenditures: Does spending matter? American Journal of Economics and Sociology, 54(October), 397-412. https://doi.org/10.1111/j.1536-7150.1995.tb03243.x

Hemelt, S. W., \& Marcotte, D. E. (2011). The impact of tuition increases on enrolment at public colleges and universities. Educational Evaluation and Policy Analysis, 33(4), 435-457. https://doi.org/10.3102/0162373711415261

Hillman, N. W. (2012). Tuition discounting for revenue management. Research in Higher Education, 53(3), 263-281. https://doi.org/10.1007/s11162-011-9233-4

Holmes, J. (2009) Prestige, charitable deductions and other determinants of alumni giving: Evidence from a highly selective liberal arts college. Economics of Education Review, 28, 18-28. https://doi.org/10.1016/j.econedurev.2007.10.008

Houle, J. N. (2014). Disparities in debt: Parents' socioeconomic resources and young adult student loan debt. Sociology of Education, 87(1), 53-69. https://doi.org/10.1177/0038040713512213

Hunter, C. S., Enid, B. J., \& Boger, C. (1999). A study of the relationship between alumni giving and selected characteristics of alumni donors of Livingstone College, NC. Journal of Black Studies, 29, 523-39. https://doi.org/10.1177/002193479902900404

Iskhakova, L., Hilbert, A., \& Joehnk, P. (2020). Crosscultural research in alumni loyalty: An empirical study among master students from German and Russian universities. Journal of Nonprofit and Public Sector Marketing. https://doi.org/10.1080/10495142.2020.1760995

Kaplan, A. E. (2012). 2011 Voluntary support of education. New York, NY: Council for Aid to Education.

Kaplan, A. E. (2017). Voluntary support of education 2016. New York, NY: Council for Aid to Education.

Lara, C., \& Johnson, D. K. N. (2008). The anatomy of a likely donor: Econometric evidence on philanthropy to higher education. Colorado College Working Paper, No. 2008/05, Colorado College. Colorado Springs Co. https://doi.org/10.2139/ssrn.1157052

Lertputtarak, S., \& Supitchayangkool, S. (2014). Factors influencing donations. International Journal of Business and Management, 9(3). https://doi.org/10.5539/ijbm.v9n3p170

Leslie, L., \& Ramey, G. (1988). Donor behavior and voluntary support for higher education institutions. Journal of Higher Education, 59(2), 115-132. https://doi.org/10.2307/1981689

Liu, Y. (2006) Determinants of private giving to public colleges and universities. International Journal of Educational Advancement, 6(2), 119-140. https://doi.org/10.1057/palgrave.ijea.2150014

Macdonald, C., \& Stratta, E. (2001). From access to widening participation: Responses to the changing population in higher education in the UK. Journal of Further and Higher Education, 25(2), 249-258. https://doi.org/10.1080/03098770120050909

Markoff, R. M. (1978). An analysis of the relationship of alumni giving and level of participation in voluntary organizations: A case study. Toledo, $\mathrm{OH}$ : University of Toledo.

Marr, K. A., Mullin, C. H., \& Siegfried, J. J. (2005). Undergraduate financial aid and subsequent alumni giving behavior. The Quarterly Review of Economics and Finance, 45, 123-143. https://doi.org/10.1016/j.qref.2003.08.005 
Mael, F., \& Ashforth, B. E. (1992). Alumni and their alma mater: A partial test of the reformulated model of organizational identification. Journal of Organizational Behavior, 13, 103-123. https://doi.org/10.1002/job.4030130202

McDearmon, J. T., \& Shirley, K. (2009). Characteristics and institutional factors related to young alumni donors and nondonors. International Journal of Educational Advancement, 9, 83-95. https://doi.org/10.1057/ijea.2009.29

McDearmon, J. T. (2013). Hail to thee, our alma mater: Alumni role identity and the relationship to institutional support behaviors. Research in Higher Education, 54(3), 283-302. https://doi.org/10.1007/s11162-012-9271-6

Meehan, C., \& Howells, K. (2018). What really matters to freshers? Evaluation of first year student experience of transition into university. Journal of Further and Higher Education, 42(7), 893-907. https://doi.org/10.1080/0309877X.2017.1323194

Meer, J., \& Rosen, H. (2012). Does generosity beget generosity? Alumni giving and undergraduate financial aid. Economics of Education Review, 31(1), 890-907. https://doi.org/10.1016/j.econedurev.2012.06.009

Melchori, G. S. (1988). Alumni research: Methods and applications. New Directions for Institutional Research. https://doi.org/10.1002/ir.37019886003

Monks, J. (2003). Patterns of giving to one's alma mater among young graduates from selective institutions. Economics of Education Review, 22(2), 121-130. https://doi.org/10.1016/S0272-7757(02)00036-5

Moody, J. (2018). 10 universities where the most alumni donate. Retrieved September 28th, 2019, from https://www.usnews.com/education/best-colleges/the-short-list-college/articles/universities-where-the-mostalumni-donate

Moore, S., \& Kuol, N. (2007). Retrospective insights on teaching: Exploring teaching excellence through the eyes of the alumni. Journal of Further and Higher Education, 31(2), 133-143. https://doi.org/10.1080/03098770701267598

Mosser, J. W. (1993). Predicting alumni/ae gift giving behavior: A structural equation model approach. ERIC Document Reproduction Service No. ED 355883.

Okunade, A. A. (1993). Logistic regression and probability of business school. Education Economics, 1, $243-262$. https://doi.org/10.1080/09645299300000030

Okunade, A., Wunnava, P. V., \& Walsh, R. (1994). Charitable giving of alumni: micro-data evidence from a large public university. American Journal of Economics and Sociology, 53(1), 73-84. https://doi.org/10.1111/j.1536-7150.1994.tb02674.x

Pallant, J. (2016). SPSS survival manual (6th ed.) Maidenhead: Open University Press. 57-58.

Pike, G. R. (1993). The Relationship Between Perceived Learning and Satisfaction with College: An Alternative View. Research in Higher Education, 34(1), 23-40. https://doi.org/10.1007/BF00991861

Pike, G. R. (1994). The relationship between alumni satisfaction and work experiences. Research in Higher Education, 35(1), 105-124. https://doi.org/10.1007/BF02496664

Reay, D., Ball, S. J., \& David, M. (2002). 'It's taking me a long time but I'll get there in the end': Mature students on access courses and higher education choice. British Educational Research Journal, 28(1), 5-19. https://doi.org/10.1080/01411920120109711

Rudolph, B. (2017). The Importance of soft skills in the hiring process. Retrieved from https://www.skywatersearch.com/post/importance-soft-skills-hiring-process

Siddiqui, K., \& Bruggink, T. H. (1995). 'An econometric model of alumni giving: A case study for a liberal arts college. American Economist, 39(2), 53-60. https://doi.org/10.1177/056943459503900206

Skari, L. A. (2014). Community college alumni: Predicting who gives. Community College Review, 42(1). https://doi.org/10.1177/0091552113510172

Stephenson, A., \& Yerger, D. (2014). Optimizing engagement: Brand identification and alumni donation behaviours. International Journal of Educational Management, 28(6), 765-778. https://doi.org/10.1108/IJEM-04-2013-0057

Sturtevant, W. (2003). Vice President of Trust Relations and Planned Giving, University of Illinois Foundation (June 4, 2003). Keynote Address. Association for Arts and Sciences Professionals. 
Sun, X., Hoffman, S. C., \& Grady, M. L. (2007). A multivariate causal model of alumni giving: Implications for alumni fundraisers. International Journal of Educational Advancement, 7, 307-332. https://doi.org/10.1057/palgrave.ijea.2150073

Sung, M., \& Yang, S. (2008). Toward the model of university image: The influence of brand personality, external prestige, and reputation. Journal of Public Relations Research, 20(4), 357-376. https://doi.org/10.1080/10627260802153207

Sung, M., \& Yang, S. U. (2009). Student-university relationships and reputation: A study of the links between key factors fostering students' supportive behavioral intentions toward their university. Journal of Higher Education, 57, 787-811. https://doi.org/10.1007/s10734-008-9176-7

Szalavitz, M. (2012). Is human nature fundamentally selfish or altruistic? Retrieved from http:/healthland.time.com/2012/10/08/is-human-nature-fundamentally-selfish-or-altruistic/

Tabachnick, B., \& Fidell, L. (2013). Using multivariate statistics (6th ed.). Pearson.

Taylor, A. L., \& Martin, J. C. (1995). Characteristics of alumni donors and non-donors at a research I, public university. Research in Higher Education, 36(3), 283-302. https://doi.org/10.1007/BF02208312

Terry, N., \& Macy, A. (2007). Determinants of alumni giving rates. Journal of Economics and Economics Education Research, 8(3), 3-18.

Tinto, V. (1993). Leaving college: Rethinking the causes and cures of student attrition (2nd ed.) Chicago, IL: University of Chicago Press. https://doi.org/10.7208/chicago/9780226922461.001.0001

Tsao, J. C., \& Coll, G. (2005). To give or not to give: Factors determining alumni intent to make donations as a PR outcome. Journalism and Mass Communication Educator, 59(4), 381-392. https://doi.org/10.1177/107769580405900407

Turton, T. (2017). Which university degrees are worth the most? Retrieved October 27th, 2021, from https://www.adzuna.co.uk/blog/2017/07/18/which-university-degrees-are-worth-the-most/

UCU. (2020). Impact of the COVID-19 pandemic on university finances. Retrieved September 16th, 2020, from https://londoneconomics.co.uk/wp-content/uploads/2020/04/LE-Impact-of-Covid-19-on-university-finances -FINAL.pdf

Weale, S. (2017). Annual donations to UK universities pass £1bn mark for first time. Retrieved September 28th, 2019,

from https://www.theguardian.com/education/2017/may/03/annual-donations-to-uk-universities-passes-1bn-mark -for-first-time

Weerts, D. J., \& Ronca, J. M. (2007). Profiles of supportive alumni: Donors, volunteers, and those who 'do it all'. International Journal of Educational Advancement, $20-34$. https://doi.org/10.1057/palgrave.ijea.2150044

Weerts, D. J., \& Ronca, J. M. (2008). Characteristics of alumni donors who volunteer at their alma mater. Research in Higher Education, 49, 274-292. https://doi.org/10.1007/s11162-007-9077-0

Weerts, D. J., \& Hudson, E. (2009). Engagement and institutional advancement. New Directions for Higher Education, (147), 65-74. https://doi.org/10.1002/he.359

Weerts, D. J., \& Ronca, J. M. (2009). Using classification trees to predict alumni giving for higher education. Education Economics, 17(1), 95-122. https://doi.org/10.1080/09645290801976985

Caboni, T. C., \& Eiseman, J. (2003, October). Organizational identification and the voluntary support of higher education. Paper presented at the Association for the Study of Higher Education annual meeting.

Adzuna. (2021). Value my degree. Retrieved April 6th, 2021, from https://adzuna.co.uk/value-my-degree/

\section{Copyrights}

Copyright for this article is retained by the author(s), with first publication rights granted to the journal.

This is an open-access article distributed under the terms and conditions of the Creative Commons Attribution license (http://creativecommons.org/licenses/by/4.0/). 